gravels were laid down, the valleys around did not exist, and also whether there was any general agreement as to the origin of the gravel; to which $\mathrm{Mr}$. Whitaker replied that he thought there was a considerable difference of opinion as to the origin of the gravel.

On leaving this section the party walked through Walton village to the church, where the Norman lead font was inspected. Continuing the walk across the fields Frythe Park was reached, where Mr. and Mrs. Stebbing had invited the party to tea. After tea, the President heartily thanked the Directors of the excursion, and the members walked across Walton Heath to Kingswood Station in time for the 7.30 train to London.

\title{
REFERENCES.
}

Geological Survey Map, Sheet 8 (Drift Edition). Price 8s. 6d. Ordnance Survey Map, New Series, Sheet 286. Price Is.

1862. Whitaker, W.- "On the Western End of the London Basin," etc. Quart. Fourn. Geol. Soc., vol. xviii, p. 258.

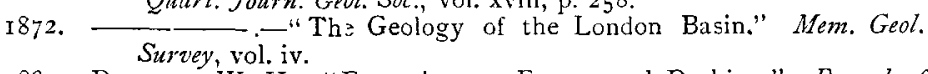

1884. DaLTON, W. H.-"Excursion to Epsom and Dorking." Record of Excursions, p. 86.

1895. Monckion, H. W., and Stebing, W. P. D.-"Excursion to Betchworth and Headley." Froc. Geol. Assoc., vol. xiv, p. I24.

\section{EXCURSION TO UPPER WARLINGHAM AND WORMS HEATH,}

\author{
SATURDAY, JULy 9TH, I 898 .
}

Director: W. Whitaker, B.A.Lond., F.R.S., Pres. G.S. Excursion Secretary: A. E. SAlTer, B.Sc., F.G.S.

(Report by Mr. SALTER and DR. G. J. HINIDE, F.R.S.)

THE party left London by the I.40 p.m. train, reaching Upper Warlingham Station at 2.15. Mr. Whitaker led the way to the pits at Whiteleaf, north of the station, where about ${ }_{5}$ feet of chalky valley-gravel is being worked. Remains of Rhinoceros and Reindeer occur here, and a portion of a tooth of Elephas primigenius, was found by Dr. Johnston-Lavis during the visit. Dr. Hinde, at the request of Mr. Whitaker, gave an account of the composition of the gravel, and made special reference to the large blocks of conglomerate seen in the pit. Some of these blocks could be shown to have been derived from Tertiary beds higher up the valley but others of a more sandy nature had not been detected in situ. The party then proceeded to Worms

Novemibr, i 898.] 
Heath, where there is a fine section in an outlier of Blackheath Beds. Towards the base the pebbles had become cemented by iron oxide into a hard conglomerate. Sand occurred below the pebble beds, and between the two was a thin band of allophane; numerous specimens of this mineral were obtained. The amount of oxide of iron present gave the section a vivid red appearance. In spite of a long search, nothing beyond flint pebbles was found although on previous occasions a few quartzite pebbles of unknown derivation had been obtained by Dr. Hinde. Above the Blackheath Beds was to be seen a quantity of drift material, derived from Blackheath Beds and Thanet Sand. A short walk through a picturesque plantation brought the members to the edge of the dry Chalk valley, and the magnificent view there obtained was thoroughly enjoyed by all. A steep descent was made to the main road, and Upper Warlingham was again reached. Here the members enjoyed the hospitality of the Rev. T. T. Griffith, M.A., amidst the sylvan beauties which surround his home. Hearty votes of thanks to the Director and to the Rev. Mr. Griffith concluded an instructive excursion.

REFERENCES.

Geological Survey Map, Sheet 6 (Drift). Price 8s. $6 \mathrm{~d}$.

Ordnance Survey Map, New Series, Sheet 286. Price Is.

I872. WhitakeR, W.- "Geology of the London Basin." Mem. Geol. Survev, vol. iv.

I896-7. Hinde, G. J.- "Notes on the Gravels of Croydon." Trans. Croydon Microscop. and Nat. Hist. Club.

1898. Salter, A. E.- "Pebbly and other Gravels in Southern England." Proc. Gecl. Assac., vol. xv, pp. $275^{-276}$.

\section{EXCURSION TO SHEPPEY.}

Saturday, July i6Th, i898.

Directors: W. Whitaker, F.R.S., Pres. Geol. Soc., T. V.

Holies, F.G.S., and W. H. Shrubsole, F.G.S.

Excursion Secretary: A. E. SALter, B.Sc., F.G.S.

(Report by THE DIRECTORS.)

About forty members left London by the 9.56 a.m. train, arriving at Sheerness at noon, and drove thence to East End Lane, where the vehicles were left and the journey continued by the cliff path on foot. Near at hand was the only remaining Coastguard Station of four which had been erected; the other three have been entirely swept away by the erosion of the coast, and their sites are now well out on the foreshore.

In the cliff section, above the London Clay, the Lower Bagshot Beds were seen, standing almost perpendicularly, and capped

November, 1898 .] 